\title{
David Staines, ed., The Cambridge Companion to Alice
} Munro

\section{Corinne Bigot}

\section{(2) OpenEdition \\ 1 Journals}

Electronic version

URL: https://journals.openedition.org/ces/4794

DOI: $10.4000 /$ ces.4794

ISSN: 2534-6695

\section{Publisher}

SEPC (Société d'études des pays du Commonwealth)

\section{Printed version}

Date of publication: 1 September 2016

Number of pages: 127-128

ISSN: 2270-0633

\section{Electronic reference}

Corinne Bigot, "David Staines, ed., The Cambridge Companion to Alice Munro", Commonwealth Essays and Studies [Online], 39.1 | 2016, Online since 05 April 2021, connection on 18 June 2021. URL: http:// journals.openedition.org/ces/4794 ; DOI: https://doi.org/10.4000/ces.4794

This text was automatically generated on 18 June 2021.

\section{(c) $(1) \odot$}

Commonwealth Essays and Studies is licensed under a Licence Creative Commons Attribution - Pas d'Utilisation Commerciale - Pas de Modification 4.0 International. 


\title{
David Staines, ed., The Cambridge Companion to Alice Munro
}

\author{
Corinne Bigot
}

\section{REFERENCES}

David Staines, ed. The Cambridge Companion to Alice Munro. Cambridge: Cambridge University Press, 2016. 210 p. ISBN 978-I-107-09327-0 (hardback); 9786I-10764720060 (paperback) and 9781316144831 (online)

1 The volume comprises ten original essays analyzing Alice Munro's work. Although some thirty books and special journal issues on Munro have already been published in English to date, this volume offers several relevant and original insights into what makes Alice Munro's writing unique. Canadian critics and writers have pride of place and the volume includes only three essays by European critics, which is a slight disappointment given the vitality of Munro criticism in Europe, as demonstrated by David Staines's bibliography at the end of the volume. However, all authors come across as passionate readers of Alice Munro's stories, and most authors are particularly perceptive Munro scholars. The volume boldly shies away from a chronological approach and the authors either deal with several stories from various collections, or study one particular collection. Curiously enough, several (and maybe too many) essays focus on Lives of Girls and Women, which Munro published in 1971 as a "novel." By contrast, stories from the 1990 s and early 2000 s are somewhat neglected, except by Ventura and Löschnigg.

2 Many essays highlight Munro's distinctive stylistic devices and analyze her patterns the volume's strong point. Several authors converge, emphasizing repetition and contrast, likeness and dissimilarity, subversion and reversal, recursion and resurgence, and a poetics of the "and" at work in Munro's fiction.

3 David Staines's chapter serves as an introduction to the Canadian writer's world (focusing on the Ontario setting) and can be especially useful to readers unfamiliar with 
Alice Munro. In her in-depth essay on space (chapter 2), Merilyn Simonds reveals the psychological and emotional dimension of space in Munro's stories, showing that Munro "excavates" the places her characters inhabit just as she "peels back" her characters' skins (42) and ruthlessly explores their moral dilemmas. Simonds convincingly shows that Munro's interest lies in the invisible, the unknown, a "fourth dimension through which she reveals the past and present and future" (35). In Munro's fictional world, she argues, place is a "shifty thing" (34) and a "chimera" (26), but it nevertheless forms its "bedrock" (42). The third chapter by Douglas Glover offers an insightful analysis of the way Munro composes her stories, by "dramatic antithesis" (45). This does not refer to her taste for oxymora, but to how paragraphs and stories are constructed - statements provoke counter-statements, contraventions, and, most importantly, subversion (45). As he analyzes a pattern of repetition and contrast in Lives and Girls and Women, Glover shows that "resistance, complexity and difference are the essential characteristics" of her style (54). Although the essay focuses on Lives, it also sheds light on the patterns at work in Munro's writing and applies to her other stories. Maria Löschnigg's essay on Munro's "undogmatic" feminism (chapter four) enriches previous feminist readings of Munro as she pursues Adrian Hunter's analysis of Munro's critique of fixed discourses - the idea that Munro criticises master discourses and avoids the trap of replacing them with other binary systems of thought. Löschnigg explains that Munro's interest lies in exposing unbalanced power relationships and not only male chauvinism. Löschnigg analyses "Haven" and "Material" to show that Munro exposes women's roles as accomplices in these unbalanced relationships. Insisting that Munro's writing often forces us to accept several truths, Löschnigg highlights Munro's tendency to favor "this and the other, instead of an either/or opposition," (61) and thus offers a glimpse of Munro's poetics of inclusion.

4 The next two chapters are of a more limited scope. Coral Ann Howells's essay on Munro's "life writing" focuses on a few autobiographical stories, notably from The View From Castle Rock, and the "finale" in Dear Life - four stories that she reads as "a daughter's story of survival," claiming that even though "Munro's mourning of her lost mother is incomplete," she performs a kind of "exorcism" through "Dear Life" (93). Margaret Atwood returns to Lives of Girls and Women where she identifies four patterns the Drowning Maiden, the Crazy Person, the Failure and the Storyteller.

5 In "Re-reading The Moons of Jupiter," W. H. New may seem to concern himself himself with only one collection and its structure, but many of his remarks actually apply to most collections. This is the case for instance with his argument that separation leads to connection while connection breaks into fragment (121), or with his comments on the importance of lines (126) and the role of food in sensory experience (131-2). Commenting on recent trends in Munro criticism that have tried to identify a "later" style in her fiction, Robert McGill (chapter 8) argues that Munro's career has been marked by continuity and recursion rather than transformation, offering the idea of a "poetics of recursion" at work in her writing (137), which he traces through the recurring and fertile motif of the train in her fiction. In "The Female Bard" (chapter 9), Héliane Ventura studies the way Munro introduces vital relationships between the short story, the Lied, the lay, the folktale, the poem and the popular song (155), foregrounding the figure of the female bard. Ventura shows that Munro's intertextual and intermusical allusions (from Greek myths to Scottish ballads, skaldic poetry, and folksongs and popular culture) are often clandestine, or at best half hidden, but mark 
her "bardic prose"; she argues that reading Munro requires a collaborative partnership, not unlike bardic poetry (158). The final essay in the collection, "The Mother as Material" by Elisabeth Hay (chapter 10), which returns to the mother as material, lacks depth (Hay mostly summarizes plots) and originality. This means that, unfortunately, the volume ends on a somewhat disappointing note, after a most promising beginning - notably the essays by Simonds, Glover and Löschnigg. This reader feels that the final spot may have been filled by a more in-depth study (and cannot help thinking that the absence of scholars from Spain, Germany or Italy is all the more regrettable). Yet most essays offer pointed insights into Munro's fiction, which makes the volume a welcome addition to the already large body of Munro criticism.

\section{AUTHORS}

\section{CORINNE BIGOT}

Corinne BIGOT is a senior lecturer at the University of Toulouse-Jean Jaurès where she teaches Commonwealth Literature. She has been working on Alice Munro's stories for the past ten years. She has published over ten essays on Munro's stories; a monograph, Alice Munro: Les Silences de la nouvelle, was published in 2014 and she is the co-author with Catherine Lanone of Sunlight and Shadows, Past and Present: Alice Munro's Dance of the Happy Shades (2014). She guest-edited a special issue of Commonwealth Essays and Studies devoted to Munro $(37.2,2015)$, and co-edited With a Roar from Underground: Alice Munro's Dance of the Happy Shades with Catherine Lanone (2015). 